\title{
Culture Maintenance through Tourism by Folklore-based Teaching for Local Guide
}

\author{
Ayu Ida Savitri \\ \{ayuidasavitri@lecturer.undip.ac.id\} \\ Universitas Diponegoro, Indonesia
}

\begin{abstract}
In the digital era of industry 4.0 with the demand of environment-friendly business due to the world's alarming natural condition, natural-cultural-historical tourism using digital promotion becomes a very reasonable way to gain profit for the people involved in the business and to get benefit for the tourism sites. As most of those kinds of tourism involving folklore as the tourism attraction, the business also serves as a potential local language and culture preservation. This research shows how local people were empowered as local guide by integrating the folklore behind the tourism sites and introducing local language as a part of culture preservation through a simple English speaking teaching material, shared through the digital media, particularly social media, managed by the local community. The result shows that, gradually, after being trained and had some practices, those local people were able to be a peer trainer, training other local people to be local guide also.
\end{abstract}

Keywords: Local Language and Culture Preservation, Folklore, Tourism, Folklore-based Teaching Material, Local Guide

\section{Introduction}

As tourism promotion is extensively growing, covering many places around the world supported by the on-line or digital tourism business, particularly social media, English becomes an important language to master in the business. The English purposively used in the business are mostly simple English writing and speaking for promoting tourism sites, offering tourism attraction and guiding tourist by introducing/exposing attractive tourism event/site, describing great view/scenery of tourism event/site, explaining unique ritual/tradition or retelling famous folklore. Thus, embedding folklore in English teaching, particularly on speaking material, is beneficial for local people as commoners who need to be local guide to develop the local tourism.

This research shows how folklore is integrated into the English-Speaking Teaching materials under scaffolding English as Second Language teaching methodology purposively made to form a particular ability of guiding tourist in a simple way as most of the local people are coming from a non-English-based education background. In the learning activities, the caregivers play a role as teacher and role model showing how to be tour guide, while the recipient imitate, create and finally able to perform their competence as tour guide. The afterteaching activities covers practices in the real tourism site supported by Tourism Information Center, Cultural, Youth, Tourism and Sport Office and the Mayor. The teaching material is then developed into a digital/on line teaching material that is shared to get more volunteers that are 
trained by the newbie local guides. This circle is continued to empower the local community to hold a self-learning training.

\section{Methodology}

This qualitative-descriptive research is done to reveal the folklore behind the tradition, legendary, religious, culinary, shopping tourism site/event using Dundes [1] folklore research method. Those folklores were selected using Purposive Sampling Technique [2] to select the mostly visited site/event by foreigners to be promoted in English. Next, the identification method was done to collect written and oral data. The written data were obtained by using Documentation Method [3] by searching information from internet and official document from local government. The oral data were obtained by observing the site/event and getting information using Participatory Observation, Note Taking and Recording Techniques [3] to juru kunci (people who understand the folklore). Then, the interpretation method was executed by interpreting the obtained folklore to get a brief description, narration and exposition of the folklore.

The folklore, along with the tourism (site) description, is then translated from Javanese with Pekalongan dialect and Indonesian into English by highly considering at two kinds of adaptation: structural and semantical [4]. The structural adaptation resulted in cultural shift form, while the semantical one resulted in meaning shift. Shift is form and meaning change from SL into TL that can be divided into level and category shifts [5]. The level shift happens when the translated text is in a different linguistic level, while the category shift happens when the translated text in TL has language change (structural, word class, language unit and language intra-system shift).

When there is no translation in the TL due to different cultural background. It is suggested to use the original language equipped with footnote or glossary referred to the text to fully explain it [6]. To avoid shift, it is advised to use two translation methods and seven translation procedures [7]. The first one is 'direct translation' where the translation resembles a quotation of the text in SL with three translation procedures called 'borrowing' or using the term in the SL, 'calque' or changing the syntactical structure of the SL, and 'literal translation' or translating word by word. The second one is 'oblique translation' where translator interpret, elaborate or summarize the explicit content of the SL with four translation procedures called 'transposition' or changing the word class of the SL, 'modulation' or changing the text form using different perspective, 'equivalence or reformulation' or using different stylistic and structure, and 'adaptation' or adapting the situation in SL into TL as there is no similar situation in TL like the situation in SL.

The translated folklores and the tourism (site) description are then being integrated into a simple English writing and speaking teaching materials covering how to introduce/expose tourism event/site, describe the view/scenery of tourism event/site, explain the ritual/tradition or retelling the folklore given to the ambassador of the city and the local people (commoners) involving in tourism business as the working partner of Cultural, Youth, Tourism and Sport Office who are later serve as trainers for the next trainees. 

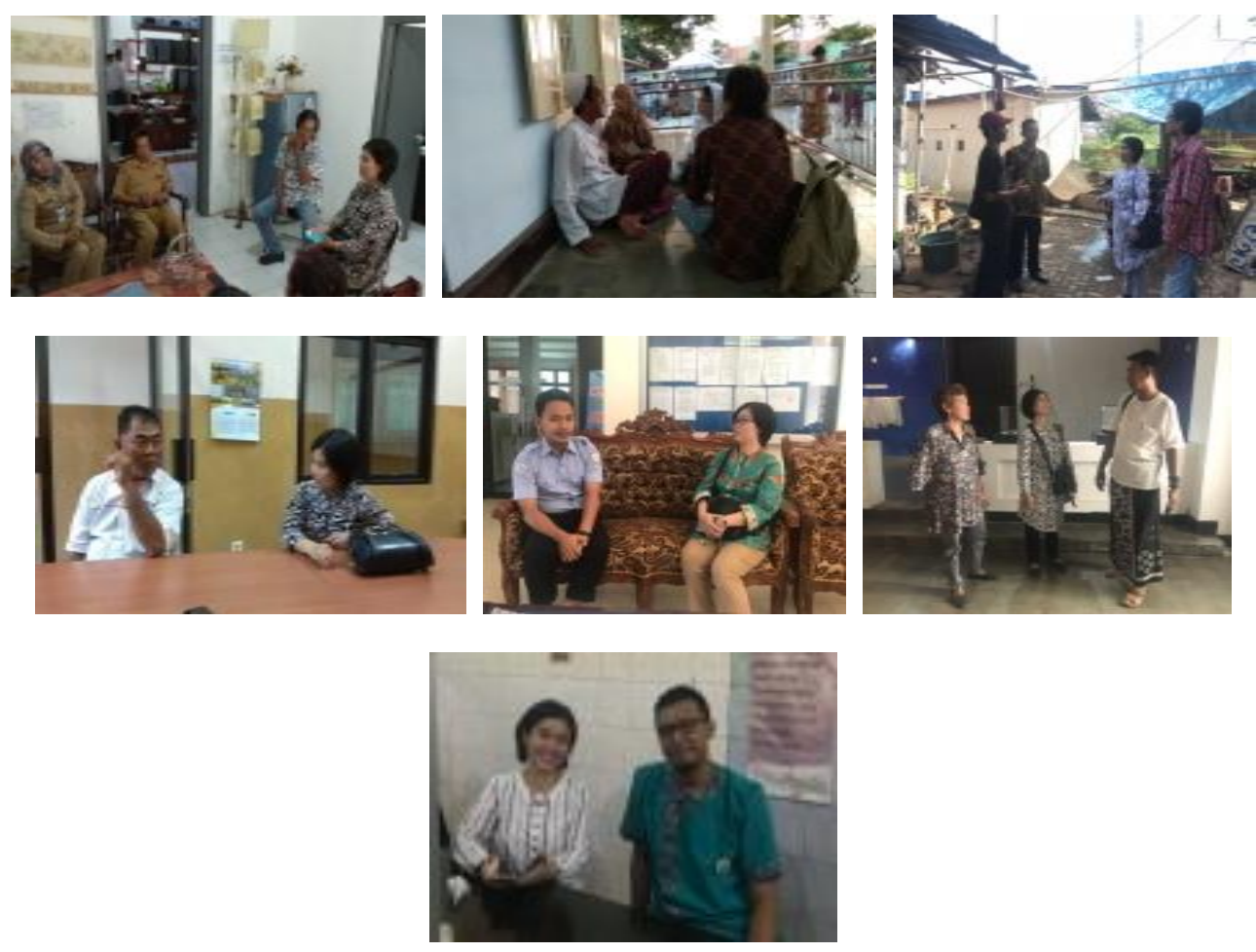

Fig. 1-7. Some of the folklores data collection.

\section{Findings and Discussion}

\subsection{Findings}

\subsubsection{Folklore Research}

As the city of batik, after batik (a particular way of creating clothes using canting to draw the motive or 'batik stamp' to print the motive on the cloth) was established as the world heritage by the United Nation and the country and the city established October, $2^{\text {nd }}$, as national batik day, Pekalongan also have another type of tourism, as follows.

Table 1. Folklore-Based Tourism Types in Pekalongan City

\begin{tabular}{cccccc}
\hline No. & $\begin{array}{c}\text { Folklore } \\
\text { Tourism }\end{array}$ & $\begin{array}{c}\text { Ocean-based } \\
\text { Tourism }\end{array}$ & $\begin{array}{c}\text { Culinary } \\
\text { Tourism }\end{array}$ & $\begin{array}{c}\text { Shopping } \\
\text { Tourism }\end{array}$ & $\begin{array}{c}\text { Cultural } \\
\text { Tourism }\end{array}$ \\
\hline \multirow{2}{*}{1} & $\begin{array}{c}\text { Tourism related } \\
\text { to the local } \\
\text { legend }\end{array}$ & $\begin{array}{c}\text { Tourism related } \\
\text { to the local } \\
\text { beach }\end{array}$ & $\begin{array}{c}\text { Tourism related } \\
\text { to the local } \\
\text { culinary }\end{array}$ & $\begin{array}{c}\text { Tourism } \\
\text { related to the } \\
\text { local batik }\end{array}$ & $\begin{array}{c}\text { Tourism } \\
\text { related to the } \\
\text { local history }\end{array}$ \\
\hline
\end{tabular}




\begin{tabular}{ccccc}
\hline $\begin{array}{c}\text { Tourism related } \\
\text { to the local } \\
\text { tradition }\end{array}$ & $\begin{array}{c}\text { Tourism related } \\
\text { to the local } \\
\text { sea }\end{array}$ & $\begin{array}{c}\text { Tourism related to } \\
\text { the local culinary } \\
\text { from sea }\end{array}$ & $\begin{array}{c}\text { Tourism } \\
\text { related to the } \\
\text { local souvenir }\end{array}$ & $\begin{array}{c}\text { Tourism } \\
\text { related to the } \\
\text { local art }\end{array}$ \\
\hline
\end{tabular}

Among them, I select Habib Ahmad Khaul (Legend-based Tourism) and Syawalan (Tradition-based Tourism), Slamaran Indah Beach (Legend and Beach-based Tourism), Sego Megono (Culinary-based Tourism), Batik Kampoong and Batik Museum (Batik as souvenir and Batik History Tourism) and Pekalongan Sintren (Art-based Tourism) as the mostly visited tourism sites/events by foreigners in Pekalongan City. The result of the folklore research of the whole seven tourism sites/events can be obtained in Appendices 1.
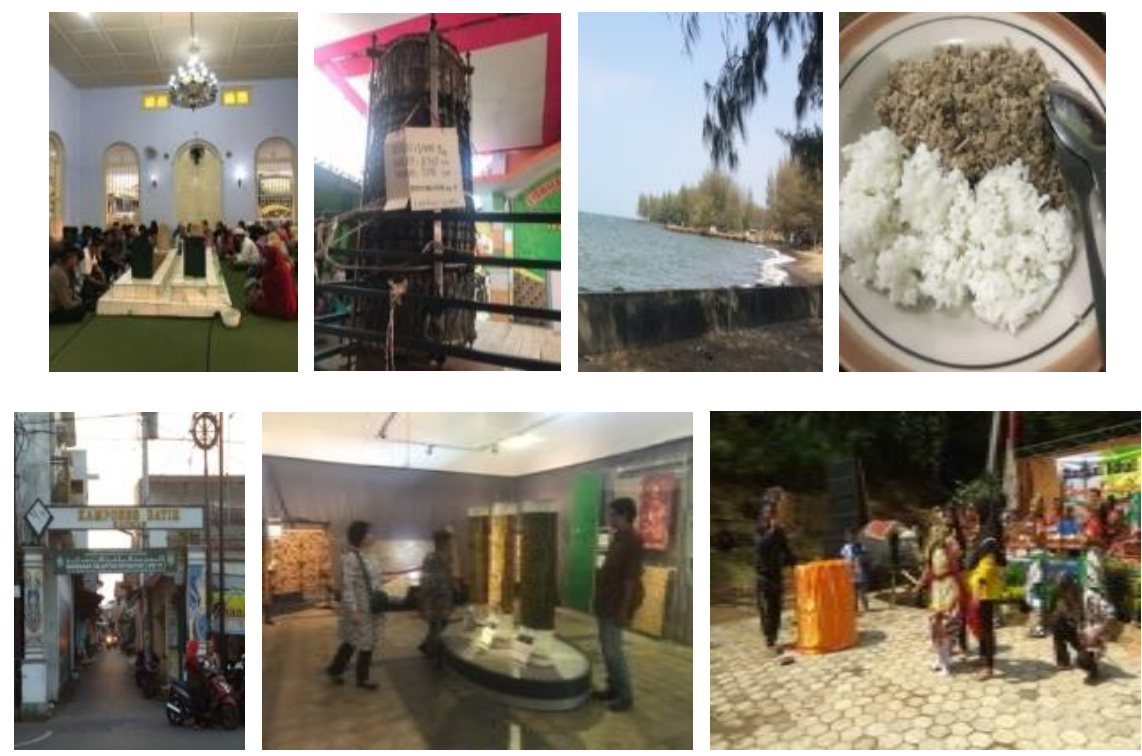

Fig. 8-14. The chosen folklores.

\subsubsection{Folklore Translation Research}

The term that cannot be translated or might cause bias/conflict potency if it is translated is presented in its original language added with notes to explain the untranslated term in English, such as " $k$ haul, commemorating Islamic great/holy figure death date". There are also terms that must be translated using direct method to avoid shift/misunderstanding. It is done by (1) applying borrowing technique in translating the term "khaul" as it is borrowed from Arabic, (2) applying calque technique in translating "Museum Batik" into "Museum of Batik" resembling the structure of the Indonesian, and (3) applying literal technique in translating "Penguasa Pantai Utara" into "the ruler of the Northern Sea".

Other terms should be translated using oblique method to make the translation understandable and enjoyable to read. It is done by (1) applying transposition technique in translating the term "Sego Megono" into "Megono Rice", (2) applying modulation technique in translating "Pranggok or Dapur Batik" into "Batik Workshop" instead of "Batik Kitchen", (3) applying equivalence or reformulation technique in translating "pemotongan Lopis raksasa" into "cutting the giant Lopis" as the one which is being cut is a giant Lopis that cannot be sliced like 
the usual size of the Lopis, and (4) applying adaptation technique in translating "kesurupan" into "trance condition" not "being possessed" as the dancer condition when she is dancing is similar with common dancer who are in trance condition due to the deep love of the music or the effect of consuming alcoholic drink/drugs unlike someone who is being possessed and say/do things irrationally. The translation process can be obtained in Appendices 2, while the translation product can be obtained in Appendices 3.

\subsection{Discussion}

\subsubsection{The Folklore-Based English Speaking and Writing Teaching Materials}

The following examples are part of the conversation or the written material used in the classroom for the city ambassador and the office working partners who later on serve as trainers for another local people who want to be local tour guide and then also posted on the social media as learning materials providing simple English for Describing People, Object and Place; Narrating Story and Process; and Exposing Fact or Opinion related to folklore, local language, culture and tourism in Pekalongan City. The complete materials can be obtained in Appendices 4.

\subsubsection{Describing People for Tourism Related to Local Legend}

Habib Ahmad (Al Habib Ahmad bin Abdullah bin Tholib Al Athas) known as Mbah Sapuro is a holy figure spreading Islam in Pekalongan. He was born in Hajeriem, Hadramaut, Yemen on 1255 Hijriyah (1836 A.D.) He spread Islam in Southeast Asia by choosing Indonesia, particularly Pekalongan, because many merchants from Hadramaut came here to sell their goods and Pekalongan people at that time were lack of Islamic religious practices. He passed away on Sunday night $24^{\text {th }}$ Rajab 1347 Hijriya (1928 A.D.) in the age of 92. His khaul (commemoration of someone's death date) was held at $14^{\text {th }}$ Sya'ban, to follow the Nisyfu Sya'ban holy night, followed by Moslem all over the world, especially Hadramaut, as an famous annual traditionalreligious event.

\subsubsection{Describing Object for Tourism Related to Particular Product (Batik)}

Batik is a valuable cloth for Javanese. It is made in several steps before we can finally use it as clothing or any other usage. There are many patterns of batik. The most unique pattern of Pekalongan Batik is Jlamprang as Pekalongan used to have many big Jlamprang trees around the city. Pekalongan Batik has unique bright colors and various motives. It has blue color as the influence of European in the Dutch colonial's era, and green, red and yellow as the influence of Arabic, China and India whose merchants brought valuable fabrics like Patola, Sembagi and Polikat. When Patola (a fabric with a double woven demanded by the upper society) was out of stock, Pekalongan merchants created a substitution of Patola by making a particular motive resembling Patola known as Jlamprang.

\subsubsection{Describing Place for Tourism Related to A Historical Building}

Batik Museum in Jetayu Street Number 1, was built by the Dutch Colonials in 1906 which as A Financial Administration Office of sugar factory. It has 1149 collections, including Wayang Beber (puppet show drawn in a cloth by using batik process) made of hundred years old batik cloth. Beside old batik, donating by various batik lovers in Indonesia and the world, it 
also has modern batik from all over Indonesia such as Sumatra, Kalimantan, to Papua and even clothes from abroad which were drawn using a kind of batik process. The museum also exhibits tools to make batik including malam (wax) along with the natural coloring and allowed visitors to make their own batik. It opens daily from 8 a.m. to 3 p.m. with the entrance ticket price ranging from Rp. 5.000 for adults and Rp. 1.000 for students.

\subsubsection{Narrating Story for Tourism Related to A Beach with Famous Folklore}

Slamaran Indah Beach is believed to be the gate to Dewi Lanjar Kingdom, the ruler of the northern sea of Java Island, the subordinate of Nyi Loro Kidul, ruler of the southern sea of Java Island. She was a very young widow whose husband died shortly after their wedding. To let go of her sadness, she left her hometown to south. At Kali Opak, she met the King of Mataram Kingdom who advise her to see Nyi Loro Kidul in the southern sea. She finally made there and being her subordinate gaining power and fame throughout the northern sea. If visitors want to see or even get into her palace through the mythical the gate, they can ask the juru kunci at the entrance gate. It is said that people who enter the gate will see a palace inhabited by common human being who do normal things like us. It is also said that are people who purposively look for money there by getting inside from the gate in the morning and getting outside from there in the afternoon.

\subsubsection{Narrating Process for Tourism Related to A Particular Culinary}

Megono is one of Pekalongan best culinary item to try. It is made of minced young jackfruit which is steamed for 45 minutes with gartered-young coconut and flower of Kecombrang, a very special ingredient, and a mixed-on onion, garlic, coriander, candlenut, galanga, salt and sugar. Sego Megono or rice with Megono on top is wrapped in banana leave and commonly served with fried vermicelli, oreg tempeh (tempeh sauteed with onion, garlic, chili, soya sauce, coconut milk and salt), carrot and cucumber pickle, and sambal (chili sauce) and usually consumed with fried tempeh or tofu saluted with flour. The price is Rp. 2.000.00 to Rp. 5.000,00 per dish and served by many food stalls around Pekalongan. Megono becomes a symbol of the tight and harmonies relationship of Pekalongan society who were coming from different ancestors, like Arabic, China, India, Java and others, who came into the city as merchant long time ago. It is symbolized from the minced young jackfruit called cecek which were mawur or dispersed but sticky.

\subsubsection{Exposing Opinion for Tourism Related to A Particular Art Show}

Sintren is an art performance showing a girl dancing in a 'trans' condition accompanied with the sound of gamelan music (Javanese traditional music). Beside dancing, Sintren dancer showed a unique performance by changing clothes several times in a chicken cage in unconscious condition. Pekalongan Sintren was unique as the Sintren dancer did not have to be a virgin since a married woman can be a Sintren dancer as long as her husband allowed her to do it. According to Dirhamsyah, a Batik City Radio staff who concerns about Pekalongan art, culture and tradition, said that Pekalongan Sintren is different from any other Sintren as the dancer does not have to be virgin since married woman can serve as a dancer as long as her husband allowed her. In addition, there is a unique performance shown by a particular Pekalongan Sintren group in Panjang, led by an old ex-Sintren dancer, where the dancer is able 
to unconsciously drag herself into the cage by laying on the ground. This group can be invited with minimum charge of Rp. 3.000.000,00.

\subsubsection{Exposing Fact for Tourism Related to A Particular Tradition}

Pekalongan has a unique tradition of celebrating Syawalan (breaking 7 days fasting after Eid Al-Fitr) by cutting and distributing a Giant Lopis for the whole citizen. Lopis is a traditional snack made from glutinous rice, served with grated young coconut mixed with some salt and sprinkled on top of it to add more flavor. This year Giant Lopis weighted $1.400 \mathrm{~kg}$ with $195 \mathrm{~cm}$ height and $237 \mathrm{~cm}$ diameter, consisting of $1.000 \mathrm{~kg}$ glutinous rice, cooked in a giant pan for 3 (three) days. Lopis symbolized the harmonies relation among Pekalongan people who were coming from different ancestors, Java, Arabic, China, and India. In the past, the Dutch forbid people to hold any gathering to prevent them preparing a rebel against the Dutch. People were then creating Lopis as a reason to hold a gathering for cooking it. The ceremony usually stars at 7 a.m. where Pekalongan Mayor and his staff come into Krapyak Kidul, Gang (small alley) VIII, Pekalongan Utara by walking across the small alley. After praying, the Giant Lopis is cut into pieces and given to Pekalongan Mayor and his staff as well as people who come the alley. After that, people could take the Lopis and ate it or brought it home as a blessing for the whole year until the next Syawalan.

\subsubsection{Figures}

The following figures shows series of activities of developing of the city tourism by two teams of English Literature Undergraduate Study Program, Linguistics and Literature Departments, Faculty of Humanities, Diponegoro University, who had already reach a Memorandum of Understanding between The Rector of Diponegoro University and Pekalongan City Mayor as well as a Letter of Agreement between The Dean of Faculty of Humanities and the Head of Pekalongan Culture, Youth, Tourism and Sport Office, to develop the city's tourism and human resources related to Language and Culture.

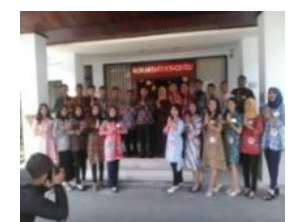

Fig. 15. Mayor Office

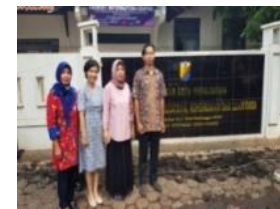

Fig. 17. Tourism Office
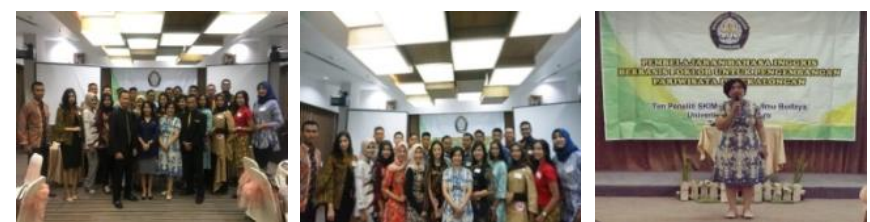

Fig. 16-18. Horison Hotel with The City Ambassador
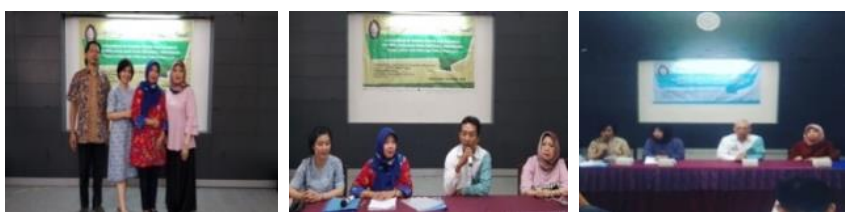

Fig. 19-21. Batik Museum Hall for Local People 

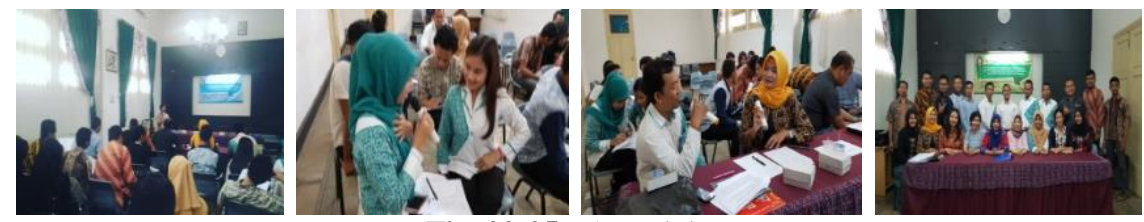

Fig. 22-25. The training

\section{Conclusion}

To develop a local tourism in a small city, the local government should know well the strength of the city that is potential be promoted throughout the world as tourism attraction such as unique folklore, interesting tourism event, great tourism site. In the digital era of industry 4.0, sometime people get bored with the whole robotic matters. Natural, historical and cultural tourism become their escape from the daily hectic activities to relax. Promoting those kinds of tourism in English, particularly by the local people, open a new opportunity for the city to expand and bear profit for the whole citizen.

\section{Acknowledgments}

Deep gratitude was expressed to Rector of Universitas Diponegoro; Mayor of Pekalongan City; Head of Pekalongan Culture, Youth, Tourism, and Sport Office; Head of Tourism Division; Dean of Faculty of Humanities, Dr. Ratna Asmarani, M.Ed., Drs. Siswo Harsono, M. Hum., Dra. Atrinawati, M.Hum., Dra. Cut Aja Puan Ellysafni, M.Ed., Dra. Wiwiek Sundari, M.Hum., Hadiyanto, M.Hum., Tri Gandi Imamudin, Dirhamsyah, all informants and respondents who were voluntarily participated in this research.

\section{References}

[1] A. Dundes, The Study of Folklore. New Jersey: Prentice Hall, 1965.

[2] S. Sugiyono, "Research Method Quantitative and Qualitative R\&D," Alf. Bandung, 2010.

[3] D. P. Sudaryanto, "Metode dan aneka teknik analisis Bahasa [Method and technique of language study]." Yogyakarta: Sanata Dharma University Press, 2015.

[4] E. A. Nida and C. R. Taber, The theory and practice of translation, vol. 8. Brill Archive, 1982

[5] J. C. Catford, A linguistic theory of translation. Oxford University Press, 1978.

[6] R. Jakobson and L. Venuti, "The translation studies reader," London New York Routledge, 2000.

[7] J.-P. Vinay and J. Darbelnet, "A methodology for translation," Transl. Stud. Read., pp. 84-93, 2000. 